THE INFLUENCE OF ATTITUDES, SUBJECTIVE NORMS, PERCEPTION OF CONTROL, AND

ORGANIZATIONAL COMMITMENT TO WHISTLEBLOWING BEHAVIOR WITH

WHISTLEBLOWING INTENTION AS A MODERATING VARIABLE(STUDY OF

CIVIL SERVANTS IN INSPECTORATE AND BPKP

REPRESENTATIVE OF JAMBI)

\title{
PENGARUH SIKAP, NORMA SUBJEKTIF, PERSEPSI KONTROL, DAN KOMITMEN ORGANISASI \\ TERHADAP WHISTLEBLOWING BEHAVIOR DENGAN INTENTION WHISTLEBLOWING SEBAGAI VARIABEL MODERASI (STUDI PADA APARATUR SIPIL NEGARA DI INSPEKTORAT DAN BPKP PERWAKILAN JAMBI)
}

\author{
Oleh: \\ Achmad Fahmi Dj ${ }^{1)}$, Afrizal ${ }^{2)}$, Ilham Wahyudi ${ }^{3)}$ \\ ${ }^{1)}$ Alumni Magister Ilmu Akuntansi Pascasarjana Universitas Jambi Tahun 2020, Bekerja di PT Bank Danamon \\ Cab. Kuala Tungkal, Jambi - Indonesia \\ ${ }^{2 \& 3)}$ Fakultas Ekonomi dan Bisnis Universitas Jambi - Indonesia \\ Email: afdjufri@gmail.com ${ }^{1)}, \underline{\text { afrizaldoktor@unja.ac.id }}$,,$\underline{\text { ilham_wahyudi@unja.ac.id }}$ (3)
}

\begin{abstract}
This study adopts the theory of planned behavior. The purpose of this study was to examine the effect of attitudes toward behavior, subjective norms, perception of control and organizational commitment to whistleblowing behavior that is moderated with whistleblowing intentions. The data collection method in this study uses a survey method while the sampling method with uses judgment sampling. Civil Servants working in the Jambi Inspectorate and BPKP are the subjects in this study. Distributed questionnaires were 100. Returning questionnaires were 80. However, only 78 questionnaires could be used in the analysis of this study. Empirical evidence in this study shows that intention significantly moderates the effect of attitudes toward behavior and subjective norms on whistleblowing behavior. However, whistlebowing intention does not significantly moderate behavior in conducting whistleblowing. The results of this study indicate that whistleblowing intentions, can strengthen the influence of attitudes toward behavior and subjective norms into a real action.
\end{abstract}

Keywords: The intention of whistleblowing, behavior planning theory, whistleblowing behavior

\begin{abstract}
ABSTRAK
Penelitian ini mengadopsi teori perilaku rencanaan. Tujuan penelitian ini untuk menguji pengaruh sikap ke arah perilaku, norma subyektif, persepsi kontrol dan komitmen organisasi terhadap perilaku whistleblowing yang dimoderasi dengan niat whistleblowing. Metode pengumpulan data dalam penelitian ini menggunakan metode survey sedangkan metode pengambilan sampel dengan menggunakan judgment sampling. Aparatur Sipil Negara yang bekerja pada Inspektorat dan BPKP perwakilan Jambi merupakan subyek dalam penelitian ini. Kuesioner yang didistribusikan sebanyak 100. Kuesioner yang kembali sebanyak 80. Namun demikian, hanya sebanyak 78 kuesioner yang dapat digunakan dalam analisis penelitian ini. Bukti empiris dalam penelitian ini menunjukkan bahwa niat signifikan memoderasi pengaruh sikap ke arah perilaku dan norma-norma subyektif terhadap perilaku whistleblowing. Namun demikian, niat whistlebowing tidak signifikan memoderasi perilaku dalam melakukan whistleblowing. Hasil penelitian ini menunjukkan bahwa niat whistleblowing, dapat memperkuat pengaruh sikap ke arah perilaku dan norma-norma subyektif ke dalam suatu tindakan nyata.
\end{abstract}

Kata Kunci: Niat whistleblowing, teori perilaku rencanaan, perilaku whistleblowing. 


\section{PENDAHULUAN}

\subsection{Latar Belakang}

Auditor memiliki peran yang sangat penting dalam pemerintahan (Mahmudah dan Riyanto,2016) dimana pada zaman sekarang ini sangat marak terjadi kasus-kasus korupsi, suap dan kasus yang melibatkan auditor pemerintahan.Salah satu buktinya adalah Bupati Pamekasan dan Inspektorat menyuap Kejari kasus dana desa (https://nasional.tempo.co) dan Eks auditor Badan Pengawas Keuangan dan Pembangunan (BPKP), Mahmud Toha Siregar, suap dari ketua panitia lelang proyek kartu tanda penduduk elektronik atau e-KTP (https://nasional.tempo.co) Dari kasus seperti itu, maka disitulah profesionalisme kerja dan intensitas moral seorang auditor dibutuhkan. Seorang auditor harus jeli dalam melakukan tugasnya. Tidak hanya mengungkapkan kewajaran, kecurangan harus diungkapkan secara gamblang. Suatu tindakan diam terhadap semua bentuk kecurangan sangat bertentangan dengan profesional internal auditor.

Menurut Standar Profesi Internal Auditor yang dikeluarkan oleh IAI pada tahun 2009 yang menyatakan bahwa Internal Auditor seharusnya memiliki sikap dan bersifat independen dan obyektif. Kemudian, apa yang harus dilakukan seorang auditor untuk mengantisipasi semakin buruknya citra auditor didalam melakukan tugasnya? Apa yang harus dilakukan seorang auditor guna mengembalikan kepercayaan masyarakat? Salah satu cara mencegah pelanggaran akuntansi sehingga bisa mengembalikan kepercayaan masyarakat adalah dengan cara menerapkan teknik pemeriksaan fraud dimana dalam akuntansi forensik dikenal dengan tindakan whistleblowing atau pemanfaatan whistleblower (Merdikawati dan Andry, 2012).

Whistleblower/peniup peluit identik dengan seseorang yang membocorkan penyimpangan di dalam organisasi, baik organisasi swasta maupun organisasi pemerintah (KNKG, 2008), Bahkan melalui whistleblowing dapat meningkatkan tata kelola dalam organisasi atau corporate governance (Bowen, Call, \& Rajgopal, 2010). Whistleblower dapat merupakan seseorang yang memang terlibat dalam penyimpangan (justice collaborator) atau mereka yang tidak terlibat dalam penyimpangann namun mengetahui adanya penyimpangan. Penyimpangan-penyimpangan yang terjadi dalam instansi pemerintah dapat juga berupa penyimpangan dari nilai-nilai suatu etika hingga berupa perbuatan korupsi.

Menjadi seorang whistleblower bukanlah suatu perkara yang mudah. Seseorang yang berasal dari internal organisasi akan menghadapi dilema etis untuk memutuskan apakah harus "meniup peluit" atau tetap membiarkannya tersembunyi. Sebagian memandang whistleblower sebagai pengkhianat yang melanggar norma loyalitas organisasi, sebagian lainnya memandang whistleblower sebagai pelindung heroik terhadap nilai-nilai kebenaran, bukan hanya sebagai loyalitas kepada organisasi (Rotshchild dan Miethe,
1999). Pandangan yang bertentangan tersebut menyebabkan calon whistleblower mengalami dilema dalam menentukan sikap yang dapat mendistorsi minat whistleblowing.

Persepsi kontrol perilaku sebenarnya didasari oleh keyakinan kontrol, maksudnya adalah faktor yang menghambat atau faktor yang mendukung individu melakukan whistleblowing. Faktor kontrol yang dilakukan perusahaan yaitu dengan cara menggagalkan atau dengan sengaja mengabaikan laporan, hal ini tentu akan menghambat individu dalam melakukan whistleblowing (Ponnu et al., 2008). Apabila individu memiliki keyakinan bahwa ia memiliki kesempatan yang besar untuk mengungkapkan wrongdoing dan tidak memiliki hambatan yang besar dalam melakukan whistleblowing, maka persepsi individu tersebut akan semakin kuat terhadap kontrol yang dilakukan ketika melakukan whistleblowing.

Di sisi lain menunjukkan bahwa adanya intention whistleblowing yang tinggi menghasilkan dampak positif terhadap sikap dan perilaku karyawan untuk suatu kebaikan yang bermanfaat bagi organisasi atau entitas, misalnya melaporkan kecurangan yang terjadi dalam organisasi. Dengan demikian, whistleblowing behavior yang dirasakan diharapkan dapat memperkuat hubungan faktor sikap dan persepsi kontrol perilaku terhadap niat seseorang untuk melaporkan tindakan kecurangan. Alleyne et al. (2013) menjelaskan pentingnya persepsi dukungan organisasi bagi individu untuk melaporkan tindakan tidak etis.

\subsection{Rumusan Masalah}

1. Apakah sikap, Norma subjektif, Persepsi Kontrol dan komitmen organisasi berpengaruh terhadap whistleblowing behavior pada Aparatur Sipil Negara?

2. Apakah sikap, Norma subjektif, Persepsi Kontrol dan komitmen organisasi berpengaruh terhadap whistleblowing behavior dengan intensi whistleblowing sebagai variabel moderasi?

\section{TINJAUAN PUSTAKA, KERANGKA PEMIKIRAN DAN HIPOTESIS}

\subsection{Tinjauan Pustaka}

\subsection{Prosocial Organizational Behavior Theory}

Brief dan Motowidlo (1986) mengartikan prosocial organizational behavior sebagai perilaku atau tindakan yang dilakukan oleh anggota sebuah organisasi terhadap individu, kelompok, atau organisasi yang ditujukan untuk meningkatkan kesejahteraan individu, kelompok, atau organisasi tersebut. Perilaku prososial (prosocial behavior) juga diartikan sebagai setiap perilaku sosial positif yang bertujuan untuk menguntungkan atau memberikan manfaat pada orang lain (Penner et al., 2005). Perilaku prososial dapat dilatarbelakangi motif kepedulian pada diri sendiri dan mungkin pula merupakan perbuatan menolong yang 
Pengaruh Sikap, Norma Subjektif, Persepsi Kontrol, dan Komitmen Organisasi Terhadap Whistleblowing Behavior dengan Intention Whistleblowing Sebagai Variabel Moderasi (Studi Pada Aparatur Sipil Negara di Inspektorat dan BPKP Perwakilan Jambi) (Achmad Fahmi Dj, Afrizal dan Ilham Wahyudi)

dilakukan murni tanpa adanya keinginan untuk mengambil keuntungan atau meminta balasan.

Prosocial behavior menjadi teori yang mendukung terjadinya whistleblowing. Brief dan Motowidlo (1986) menyebutkan whistleblowing sebagai salah satu dari 13 bentuk prosocial organizational behavior. Hal tersebut sejalan dengan pendapat Dozier dan Miceli (1985) yang menyatakan bahwa tindakan whistleblowing dapat dipandang sebagai perilaku prososial karena perilaku tersebut memberikan manfaat bagi orang lain (atau organisasi) disamping juga bermanfaat bagi whistleblower itu sendiri. Perilaku prososial dapat digunakan untuk menjelaskan pembuatan keputusan etis individual yang terkait dengan niat melakukan whistleblowing. Whistleblower melakukan pelaporan dugaan pelanggaran dalam upaya membantu korban dan memberikan manfaat bagi organisasi karena mereka yakin bahwa perbuatan pelanggaran tersebut tidak sesuai dengan nilai-nilai yang dianut oleh suatu organisasi. Pada prinsipnya seorang whistleblower merupakan 'prosocial behaviour' yang menekankan untuk membantu pihak lain dalam menyehatkan sebuah organisasi atau perusahaan (Miceli dan Near ,1988).

\subsubsection{Theory of Planned Behavior.}

Theory of Planned Behavior merupakan pengembangan Theory of Reasoned Action, dengan menambahkan konstruk yang belum ada dalam Theory of Reasoned Action yaitu persepsi kontrol atas perilaku. Seseorang dapat bertindak berdasarkan niat hanya jika seseorang memiliki kontrol terhadap perilakunya (Ajzen, 1991). Konstruk ini ditambahkan untuk memahami keterbatasan yang dimiliki individu dalam melakukan perilaku tertentu. Dengan kata lain, niat seseorang untuk melakukan suatu prilaku tidak hanya ditentukan oleh suatu sikap dan norma subjektif, tetapi juga oleh persepsi individu terhadap kontrol perilaku dengan bersumber pada keyakinan terhadap kontrol tersebut.

TPB menjelaskan bahwa niat individu untuk berperilaku ditentukan oleh tiga faktor, yaitu pertama, sikap ke arah suatu perilaku. Sikap bukanlah perilaku namun sikap menghadirkan suatu kesiap siagaan untuk tindakan yang mengarah pada perilaku(Lubis, 2010). Individu akan melakukan sesuatu sesuai dengan sikap yang dimilikinya terhadap suatu perilaku. Selain itu individu akan mengevaluasi atau menilai apakah perilaku tersebut baik untuk dilakukan atau tidak. Kedua, norma subjektif yang mengacu pada persepsi tekanan sosial yang dirasakan untuk melakukan atau tidak melakukan perilaku. Individu akan melakukan sebuah perilaku jika dianggap perilakunya dapat diterima oleh orang-orang yang dianggapnya penting dalam kehidupannya. Ketiga, persepsi kontrol perilaku yang mengacu pada kemudahan atau kesulitan yang dihadapi untuk melakukan perilaku. Pengendalian seorang individu terhadap perilakunya
TPB telah diaplikasikan dalam beberapa penelitian yaitu kepatuhan pajak(Bobek \& Hatfield, 2003), perilaku akuntan publik (Buchan, 2005), keputusan etis manajer (Carpenter dan Reimers, 2005), perilaku whistleblowing oleh Chief Financial Officer(Uddin dan Gillett, 2002), niat whistleblowing pada mahasiswa bisnis(Montesarchio, 2009), pembuatan anggaran( $\mathrm{Su}$ dan $\mathrm{Ni}, 2013)$, intensi whistleblowing pada auditor (Park \& Blenkinsopp, 2009).

Theory of Planned Behavior menjelaskan bahwa perilaku yang dilakukan oleh individu timbul karena adanya niat untuk berperilaku. Berdasarkan teori ini dapat diketahui bahwa niat terbentuk dari attitude toward behavior, subjective norms, dan perceived behavioral control yang dimiliki individu. Sikap terhadap perilaku (attitude toward behavior) merupakan evaluasi individu secara positif atau negatif terhadap benda, orang, institusi, kejadian, perilaku atau niat tertentu (Ajzen, 2005). Sikap individu terhadap suatu perilaku diperoleh dari keyakinan terhadap konsekuensi yang ditimbulkan perilaku tersebut. Apabila seseorang melakukan perilaku yang menghasilkan outcome positif, maka individu tersebut memiliki sikap positif, begitu juga sebaliknya.

Norma subjektif (subjective norm) merupakan faktor diluar individu yang menunjukkan persepsi seseorang tentang perilaku yang dilaksanakan. Subjective norms tidak hanya ditentukan referent, tetapi juga motivation to comply. Apabila individu yakin bahwa referent menyetujui dirinya melaksanakan suatu perilaku dan termotivasi mengikuti suatu perilaku, maka individu tersebut akan merasakan adanya tekanan sosial untuk melakukannya, begitu juga sebaliknya (Ajzen, 2005).

Persepsi kemampuan mengontrol perilaku (perceived behavioral control/PBC), adalah persepsi atau kemampuan diri individu mengenai kontrol individu tersebut atas suatu perilaku. PBC ditentukan oleh pengalaman masa lalu individu atau dipengaruhi pengalaman dari orang lain. Individu akan melakukan suatu perilaku jika telah mengevaluasi perilaku tersebut secara positif, adanya tekanan sosial untuk melakukan perilaku, serta individu percaya dan memiliki kesempatan untuk melakukan suatu perilaku (Ajzen, 2005).

Niat untuk melakukan perilaku (intention), merupakan komponen diri individu yang mengacu pada keinginan untuk melakukan perilaku tertentu. Menurut Ajzen,2005, Tingkah laku tidak hanya bergantung pada intensi seseorang, melainkan juga faktor lain seperti ketersediaan sumber dan kesempatan untuk menunjukkan tingkah laku tersebut. Niat terbentuk dari attitude toward behavior, subjective norms, dan perceived behavioral control yang dimiliki individu terhadap suatu perilaku. Perilaku (behavior), merupakan tindakan nyata yang dilakukan seseorang berdasarkan niat yang ada (Jogiyanto, 2007). Secara umum, teori ini menyatakan bahwa semakin besar 
dukungan sikap dan norma subyektif berhubungan dengan perilaku, maka semakin kuat intensi seseorang untuk melakukan perilaku. Semakin besar persepsi kontrol perilaku yang dirasakan, maka semakin kuat intensi seseorang untuk melakukan perilaku yang dipertimbangkan (Ajzen, 1991 dalam Respati, 2010).

Menurut Ajzen (1991) niat untuk melakukan berbagai jenis perilaku dapat diprediksi dengan tingkat keakuratan yang tinggi dari sikap seseorang terhadap perilaku, norma subyektif, dan kontrol perilaku yang dirasakan. Dalam Theory of planned behavior dijelaskan bahwa niat individu untuk melakukan suatu tindakan atau berperilaku dipengaruhi oleh beberapa faktor yaitu sikap terhadap perilaku, norma subyektif, dan persepsi kontrol perilaku

\subsubsection{Teory of Reasoned Action}

Menurut Fishbein dan Ajzen (1981), Teori Reasoned Action berasumsi bahwa hampir seluruh perilaku orang yang terkait dengan tindakan social di bawah kontrol kehendak orang tersebut. Perilaku seseorang ditentukan oleh intensinya.Sementara itu, intensi merupakan fungsi daridua faktor penentu, yaitu sifat kepribadian seseorang (yang disebut sikap) dan pengaruh sosial (yang disebut norma subjektif). Sikap ber kaitan dengan penilaian seseorang, baik positif maupun negatif, dalam melakukan suatu tindakan perilaku. Norma subjektif diartikan sebagai persepsi seseorang atas tekanan social yang dirasakannya untuk melakukan (atau tidak melakukan) perilaku tertentu. Kerangka Teori Reasoned Action dapat dilihat pada Gambar 1

Dalam konteks whistle-blowing, sesuai penjelasan Teori Reasoned Action Fishbein dan Ajzen 1975; Fishbein dan Ajzen 1981) dan pandangan Vallerand et al. (1992), bahwa tindakan whistle-blowing disebabkan adanya niatan atau intensi yang dirasakan dalam dirinya, yang disebut intensi whistle-blowing.Intensi whistle-blowing dibentuk oleh norma subjektif individu. Orang memiliki keyakinan normatif atas orang-orang yang menjadi panutan atau referensi bagi dirinya. Apabila orang berpersepsi bahwa seseorang atau kelompok orang yang menjadi panutannya menganggap whistle-blowing itu perbuatan yang baik dan bermanfaat, maka orang tersebut berusaha mematuhinya (Trongmateerut dan Sweeney 2012) dan sebaliknya. Apabila proses tersebut berakhir positif, maka norma subjektif dapat menguatkan intensi whistle-blowing dalam dirinya. Dengan demikian, semakin kuat faktor sikap dan norma subjektif terhadap proses penilaian positif tentang whistleblowing, maka semakin kuat intensinya, dan semakin kuat realisasinya melakukan whistleblowing (Curtis dan Taylor 2009)

\subsection{Model penelitian}

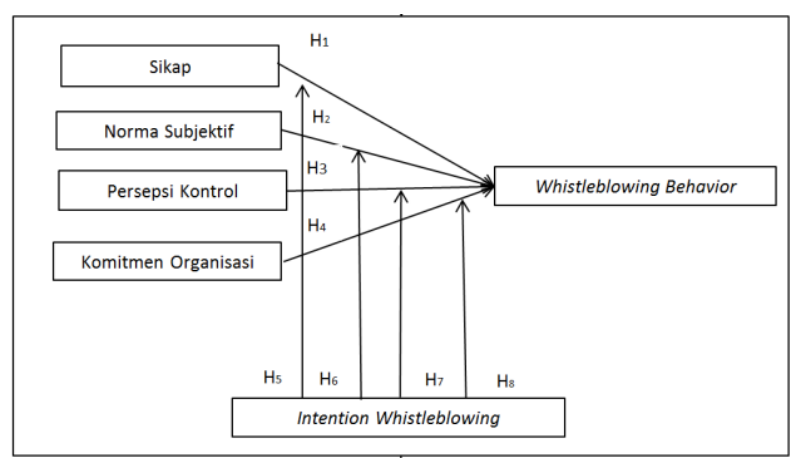

Sumber: Data Diolah Penulis

\section{Gambar 1. .Model Penelitian}

\subsection{Hipotesis}

Berdasarkan kerangka konseptual di atas dan hasil-hasil penelitian sebelumnya, hipotesis pertama yang diajukan dalam penelitian ini adalah:

H1: Sikap berpengaruh terhadap whistleblowing behavior pada Aparatur Sipil Negara.

H2: Sikap berpengaruh terhadap whistleblowing behavior Aparatur Sipil Negara Dengan Intention Whistleblowing Sebagai Variabel Moderasi

H3: Norma Subyektif Berpengaruh Terhadap whistle blowing behavior pada Aparatur Sipil Negara

H4: Norma subjektif berpengaruh terhadap whistle blowing behavior dengan intention whistleblowing sebagai variabel moderasi pada Aparatur Sipil Negara

H5: Persepsi kontrol berpengaruh terhadap whistleblowing behavior pada ASN

H6: Persepsi Kontrol Perilaku berpengaruh terhadap whistleblowing behaviour dengan intention whistleblowing sebagai variabel moderasi

H7: Komitmen organisasi berpengaruh terhadap whistle blowing behavior pada Aparatur Sipil Negara

H8: Komitmen organisasi berpengaruh terhadap whistleblowing behavior pada Aparatur Sipil Negara dengan intention whistleblowing sebagai variabel moderasi

\section{METODOLOGI PENELITIAN}

\subsection{Populasi dan Sampel}

Objek dalam penelitian ini adalah Inspektorat dan BPKP Perwakilan Jambi dan Subjek Penelitian ini adalah seluruh Aparatur Sipil Negara yang aktif di BPKP perwakilan Jambi dan Inspektorat Provinsi Jambi Populasi dalam penelitian ini adalah Aparatur Sipil Negara dari Inspektorat Provinsi Jambi dan BPKP yang berjumlah 78 orang. Metode Penelitian ini merupakan metode explanatory. Cooper dan Schindler 
Pengaruh Sikap, Norma Subjektif, Persepsi Kontrol, dan Komitmen Organisasi Terhadap Whistleblowing Behavior dengan Intention Whistleblowing Sebagai Variabel Moderasi (Studi Pada Aparatur Sipil Negara di Inspektorat dan BPKP Perwakilan Jambi) (Achmad Fahmi Dj, Afrizal dan Ilham Wahyudi)

(2017) menjelaskan metode explanatory adalah metode riset/ penelitian yang mempelajari hubungan antara dua variable atau lebih. Metode penelitian ini menggunakan pendekatan kuantitatif

\subsection{Variabel Penelitian}

Penulis mengemukakan tiga variabel yang akan diteliti. Adapun defenisi dan variabel menurut Indrianto dan Supomo (2014) adalah sebagai berikut:

1. Variabel Independen

Variabel Independen adalah tipe variabel yang menjelaskan atau mempengaruhi variabel yang lain. Variabel independen dikenal juga sebagai variabel bebas. Adapun variabel independen dalam penelitian ini adalah Sikap, Norma subjektif, persepsi control dan Komitmen Organisasi

2. Variabel Pemoderasi

Variabel pemoderasi merupakan variabel yang dalam posisi dapat memperkuat atau memperlemah hubungan antara variabel independen dan dependen yang telah diformulasi di dalam model riset. Adapun yang menjadi variabel pemoderasi dalam penelitian ini adalah Niat (Intention)

\section{Variabel Dependen}

Variabel dependen merupakan variabel utama yang menjadi daya tarik atau focus peneliti.Variabel dependen adalah tipe variabel yang dijelaskan atau dipengaruhi oleh variabel independen. Dalam Penelitian ini yang menjadi variabel dependen adalah Perilaku (Behaviour) Whistleblowing.

\section{HASIL DAN PEMBAHASAN}

\subsection{Hasil Penelitian}

4.1.1. Hasil Uji Statistik Deskriptif

Hasil uji statistik deskriptif terhadap variabel-variabel yang digunakan dalam penelitian ini yaitu sikap,norma subjektif, persepsi kontrol,Komitmen organisasi ,niat whistleblowing dan prilaku ditunjukan dalam tabel 1 berikut:

Tabel 1. Hasil Uji Statistik Descriptif

\begin{tabular}{|l|r|r|r|r|r|}
\hline & $\mathrm{N}$ & $\begin{array}{c}\text { Minimu } \\
\mathrm{m}\end{array}$ & $\begin{array}{c}\text { Maximu } \\
\mathrm{m}\end{array}$ & Mean & $\begin{array}{c}\text { Std. } \\
\text { Deviation }\end{array}$ \\
\hline SKP & 78 & 2.6942 & 4.0221 & 3.380965 & .2648723 \\
NS & 78 & 2.2636 & 4.3282 & 3.293240 & .5129159 \\
PC & 78 & 1.6 & 4.4 & 3.241 & .5351 \\
KO & 78 & 2.5779 & 4.5513 & 3.348563 & .5126481 \\
NW & 78 & 1.8701 & 4.5635 & 3.596347 & .6462789 \\
BW & 78 & 1.6336 & 4.5573 & 3.867862 & .7629283 \\
Valid N & 78 & & & & \\
(listwise) & 78 & & & & \\
\hline
\end{tabular}

\subsubsection{Hasil Pengujian Reliabilitas}

Uji reliabilitas ini dilakukan untuk menilai konsistensi dari instrumen penelitian dengan mengukur koefisien Cronbach Alpha. Suatu konstruk atau variabel dikatakan reliabel jika memberikan nilai Cronbach Alpha >0,7 (Ghozali, 2013)

Tabel 2. Hasil Uji Reliabilitas

\begin{tabular}{|l|l|l|}
\hline Item & Cronbach Alpha & Keterangan \\
\hline Sikap & 0,722 & Reliabel \\
\hline Norma Subjektif & 0,741 & Reliabel \\
\hline Persepsi Kontrol & 0,882 & Reliabel \\
\hline Komitmen Organisasi & 0,756 & Reliabel \\
\hline Niat & 0,791 & Reliabel \\
\hline Perilaku & 0,910 & Reliabel \\
\hline
\end{tabular}

Sumber: Output SPSS (2020)

\subsubsection{Hasil Uji Multikolinearitas}

Uji multikolinearitas dilakukan untuk melihat apakah terjadi korelasi antara variabel bebas atau satu dengan lainnya.

Tabel 3. Hasil Uji Multikolinearitas

\begin{tabular}{|c|c|c|}
\hline \multirow{2}{*}{ Model } & \multicolumn{2}{|c|}{ Collinearity Statistics } \\
\cline { 2 - 3 } & Tolerance & VIF \\
\hline ZcsoreSKP & 0.596 & 1.679 \\
\hline ZscoreNS & 0.191 & 5.224 \\
\hline ZscorePC & 0.411 & 2.435 \\
\hline ZscoreKO & 0.244 & 4.095 \\
\hline ModSKP & 0.365 & 2.738 \\
\hline Mod NS & 0.178 & 5.612 \\
\hline MOdPC & 0.199 & 5.022 \\
\hline Mod KO & 0.285 & 3.511 \\
\hline
\end{tabular}

Sumber: Output SPSS (2020)

\subsubsection{Hasil Pengujian Hipotesis}

Tabel 4. Hasil Pengujian Hipotesis

\begin{tabular}{|c|c|c|}
\hline & Pengujian Hipotesis & Hasil Pengujian \\
\hline 1 & $\begin{array}{llll}\begin{array}{l}\text { Pengaruh } \\
\text { behavior }\end{array} & \text { Sikap } & \text { terhadap } & \text { Whistleblowing } \\
\end{array}$ & Diterima \\
\hline 2 & $\begin{array}{l}\text { Pengaruh } \begin{array}{c}\text { Norma } \\
\text { Whistleblowing Behavior }\end{array} \\
\text { Subjektif }\end{array}$ & Ditolak \\
\hline 3 & $\begin{array}{l}\text { Pengaruh Persepsi Kontrol Perilaku terhadap } \\
\text { Whistleblowing Behavior }\end{array}$ & Diterima \\
\hline 4 & 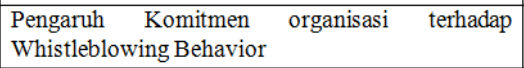 & Ditolak \\
\hline 5 & $\begin{array}{lccc}\text { Pengaruh } & \text { Sikap } & \text { terhadap } & \text { Whistleblowing } \\
\text { Behavior dengan } & \text { Whistleblowing Intention } \\
\text { sebagai variabel Moderasi } & \end{array}$ & Ditolak \\
\hline 6 & $\begin{array}{l}\text { Pengaruh Norma Subjektif terhadap } \\
\text { Whistleblowing Behavior dengan Whistleblowing } \\
\text { Intention sebagai variabel Moderasi }\end{array}$ & Ditolak \\
\hline 7 & $\begin{array}{l}\text { Pengaruh persepsi kontrol terhadap } \\
\text { Whistleblowing Behavior dengan Whistleblowing } \\
\text { Intention sebagai variabel Moderasi }\end{array}$ & Diterima \\
\hline 8 & $\begin{array}{l}\text { Pengaruh Komitmen Organisasi terhadap } \\
\text { Whistleblowing Behavior dengan Whistleblowing } \\
\text { Intention sebagai variabel Moderasi }\end{array}$ & Ditolak \\
\hline
\end{tabular}

Sumber: Data Diolah Peneliti

\subsection{Pembahasan}

Hasil uji hipotesis pertama pada Tabel 4 menunjukan bahwa terdapat pengaruh sikap terhadap Whistleblowing Behavior. Uji regresi moderating menunjukan bahwa sikap mempunyai tingkat signifikan sebesar 0,037 yang dapat dikatakan lebih kecil dari 0,05 sehingga dapat disimpulkan bahwa penelitian ini 
mendukung hipotesis pertama (H1). Hasil penelitian ini memberikan bukti empiris bahwa semakin baik sikap whistleblowing akan menaikkan perilaku (behavior) whistleblowing Aparatur Sipil Negara pemerintah .Penelitian ini sejalan dengan penelitian rustiarini \& Sunarsih (2017), Trongmateerut ( 2013 ). Tetapi hasil penelitian Tabel 4 ini tidak sejalan dengan penelitian terdahulu yang lain yang dilakukan oleh Saud (2016) dan Park \& Blenkinsopp (2009) yang menyatakan bahwa sikap tidak berpengaruh terhadap niat whistleblowing ,dan juga sejalan dengan peneliti terdahulu yang lain yang dilakukan oleh Purwantini (2016) yang menyatakan bahwa sikap tidak berpengaruh terhadap niat whistleblowing internal, hal ini dapat disebabkan oleh beberapa faktor seperti faktor emosional seseorang, lembaga (perusahaan), pengalaman pribadi ataupun karena faktor budaya. Sikap auditor tidak memiliki efek secara langsung dalam pengambilan keputusan apakah akan melakukan whistleblowing atau tidak .Terdapat perbedaan pendapat menurut Parker et al. (1992) menyatakan bahwa sikap memiliki pengaruh yang sangat lemah terhadap intensi individu untuk dalam menampilkan perilaku. Lemahnya pengaruh sikap seorang auditor menunjukan bahwa auditor seringkali mengabaikan pertimbangan apakah whistleblowing merupakan perilaku yang menguntungkan atau tidak bagi auditor .

Hasil uji hipotesis kedua pada Tabel 4 menunjukan bahwa whistleblowing intention tidak dapat memoderasi pengaruh sikap terhadap whistleblowing behavior. Uji regresi moderat menunjukan bahwa nilai signifikasi sebesar 0,874 dapat dinyatakan lebih besar dari 0,05, sehingga dapat disimpulkan bahwa penelitian ini tidak mendukung hipotesis kedua (H2). Hasil penelitian ini memberikan bukti empiris bahwa Niat (intention) tidak dapat memperkuat pengaruh sikap whistleblowing dalam menaikkan perilaku (behavior) whistleblowing.Penelitian pada model ini tidak sejalan dengan penelitian yang dilakukan oleh Salsabila (2018), Latan et al. (2017), Saud (2016) dan Kamarunzaman et al. (2012) yang menyatakan bahwa intention whistleblowing dapat memoderasi pengaruh sikap terhadap niat whistleblowing. sikap menjadi salah satu faktor yang mendukung individu untuk melaporkan tindakan tidak etis dalam organisasinya.

Pengaruh Norma Subjektif (X2) terhadap whistleblowing behavior (Y1) memiliki nilai koefisien jalur 0,784. P-values $>0,05$. Secara empiris H3 tidak terbukti dan dinyatakan ditolak. Hasil penelitian ini memberikan bukti empiris bahwa semakin tinggi norma subjektif tidak berpengaruh dalam menaikkan perilaku (behavior) whistleblowing Aparatur Sipil Negara pemerintah. Karena adanya pengaruh social yang penting dari beberapa perilaku berakar dari keluarga, pasangan hidup, kerabat, rekan dalam bekerja dan acuan lainnya yang berkaitan dengan suatu perilaku sehingga terkadang auditor dalam melakukan whistleblowing melihat dulu apakah ada hubungan vertical atau horizontal dengan pelaku kejahatan ini , sehingga norma subjektif tidak berpengaruh dalam perilaku whistleblowing Hasil ini tidak mendukung hasil penelitian Uddin dan Gillet (2005), Carpenter dan Reimers (2005), serta Hays (2013) yang menyatakan bahwa norma subjektif memiliki hubungan yang kuat dengan niat untuk melakukan whistleblowing. Di organisasi dengan ethical climate-benevolence, anggota organisasi akan menyikapi suatu peristiwa dengan memerhatikan kesejahteraan bagi orang lain. Mereka akan menolak suatu kondisi yang tidak etis dengan memerhatikan orang lain, organisasi,dan permasalahan yang melanggar ketentuan dari organisasi tersebut. Penelitian Lavena (2016) menunjukan bahwa kemauan untuk melakukan wistleblowing sangat terkait dengan norma pegawai itu sendiri dan motif dalam bekerja. Whistleblowing akan dipandang sebagai suatu cara untuk menyelamatkan orang lain, organisasi, dan nilainilai dalam organisasi itu sendiri. Organisasi dengan karakteristik benevolence yang kuat, anggota organisasi akan cenderung melaksanakan tindakan whistleblowing.

Hasil uji hipotesis keempat pada Tabel 4 menunjukan bahwa whistleblowing intention tidak dapat memoderasi pengaruh norma subjektif terhadap whistleblowing behavior. Uji regresi moderat menunjukan bahwa nilai signifikasi sebesar 0,463 dapat dinyatakan lebih besar dari 0,05 , sehingga dapat disimpulkan bahwa penelitian ini mendukung hipotesis keempat (H4). Hasil penelitian ini memberikan bukti empiris bahwa intention tidak memperkuat pengaruh norma subjektif dalam menaikkan perilaku (behavior) whistleblowing Aparatur Sipil Negara pemerintah. Penelitian ini tidak sejalan dengan penelitian Salsabila (2018) dan Kamarunzaman et al. (2012), yang menyatakan bahwa norma subjektif berpengaruh terhadap niat whistleblowing. Norma subjektif yang dirasakan merupakan salah satu faktor yang mendukung seorang individu untuk melaporkan tindakan tidak etis dalam organisasinya. Individu harus mengukur tingkat persepsi dukungan organisasi ketika ingin melakukan whistleblowing, mengingat akan muncul dampak negatif dan positif yang muncul seiring dengan whistleblowing yang dilakukan untuk itu dukungan organisasi sangat diperlukan oleh individu yang bersangkutan. Karyawan yang diperlakukan dengan baik akan cenderung lebih berkomitmen terhadap tempat kerja, dukungan organisasi juga akan mendorong karyawan untuk melaporkan whistleblowing (Kamarunzaman et al.,2013). Hal ini juga didukung penelitian yang dilakukan Abdilla (2017) berpendapat bahwa semakin tingginya ancaman (retalasi) maka niat untuk melakukan whistleblowing semakin berkurang. Hasil penelitian ini memberikan bukti empiris bahwa semakin baik Persepsi control akan menaikkan perilaku (behavior) whistleblowing Aparatur Sipil Negara pemerintah .Konstruk ini menegaskan bahwa niat seseorang untuk melakukan suatu perilaku tidak hanya ditentukan oleh sikap dan norma subjektif, tetapi juga persepsi individu terhadap kontrol perilaku. Hasil penelitian Chang (1998) menunjukkan bahwa persepsi kontrol atas perilaku 
merupakan prediktor kuat dari perilaku seseorang. Persepsi kemampuan mengontrol perilaku adalah persepsi atau kemampuan diri individu mengenai untuk mengontrol suatu perilaku, salah satunya perilaku whistleblowing. Dengan demikian apabila seorang karyawan memiliki persepsi kontrol atas perilaku untuk melakukan whistleblowing yang kuat, hal tersebut tidak sekedar ditunjukkan melalui niat atau intensi tetapi sudah dalam bentuk nyata yaitu perilaku untuk mengungkapkan kecurangan tersebut. Dapat disimpulkan bahwa hasil pengujian ini mendukung hipotesis kelima. Uji regresi moderat menunjukan bahwa tingkat signifikasi persepsi kontrol perilaku sebesar 0,00 yang dapat dikatakan lebih kecil dari 0,05 sehingga dapat disimpulkan bahwa penelitian ini mendukung hipotesis kelima (H5).Hasil ini berbeda dengan penelitian yang dilakukan Chang (1998) yang menyatakan bahwa persepsi kontrol perilaku merupakan prediktor utama yang memengaruhi perilaku tidak etis.

Hasil uji hipotesis keenam pada Tabel 4 menunjukan bahwa intention whistleblowing dapat memoderasi pengaruh persepsi kontrol terhadap whistleblowing behavior. Uji regresi moderat menunjukan bahwa nilai signifikasi sebesar 0,003dapat dinyatakan lebih kecil dari 0,05, sehingga dapat disimpulkan bahwa penelitian ini mendukung hipotesis keenam (H6). Hasil penelitian ini memberikan bukti empiris bahwa intention memperkuat persepsi control dalam menaikkan perilaku (behavior) whistleblowing Aparatur Sipil Negara pemerintah.

Hasil uji hipotesis ketujuh pada Tabel 4 menunjukan bahwa komitmen organisasi tidak berpengaruh terhadap whistleblowing behavior. Uji regresi moderat menunjukan bahwa nilai signifikasi sebesar 0,217 yang dapat dikatakan lebih besar dari 0,05 , sehingga dapat disimpulkan bahwa penelitian ini tidak mendukung hipotesis ketujuh (H7). Hasil penelitian ini memberikan bukti empiris bahwa semakin tinggi komitmen organisasi tidak menaikkan perilaku (behavior) whistleblowing Aparatur Sipil Negara pemerintah .Penelitian ini tidak sejalan dengan penelitin sebelumnya yang dilakukan oleh Salsabila (2018), Latan et al. (2017), Alleyne et al. (2013) dan Kamarunzaman et al. (2012) yang menyatakan bahwa persepsi dukungan organisasi dapat berpengaruh terhadap niat whistleblowing. Tetapi penelitian ini sejalan dengan penelitian yang dilakukan oleh Saud (2016) yang menyatakan bahwa persepsi dukungan organisasi tidak dapat memoderasi pengaruh sikap terhadap niat whistleblowing. Dukungan organisasi yang diberikan belum bisa mendorong individu untuk memiliki sikap positif agar mau melakukan whistleblowing, dikarenakan individu masih ragu sehingga mengabaikan pertimbangan bahwa memiliki niat melakukan whistleblowing merupakan hal yang penting dan positif yang menyebabkan menurunnya niatan melakukan pelaporan kecurangan (Saud, 2016).

Hasil penelitian ini sejalan dengan teori Ethical Climate Work Theory. Ethical climate work theory merupakan teori yang dikembangkan oleh Victor dan Cullen (1988) sebagai pengembangan teori moral kognitif. Terdapat dua dimensi dari teori ini, yaitu an ethical approach dimension dan an ethical referent dimension. Dimensi pertama dari ethical climate work theory terdiri dari tiga pendekatan, yaitu egoism, benelovolence, dan principle. Organisasi dengan karakteristik egoism, anggota organisasi cenderung mempertimbangkan keuntungan pribadi ketika dihadapkan pada dilema etis. Organisasi dengan tipe benevolence, anggota organisasi akan cenderung mempertimbangkan kesejahteraan orang lain. Organisasi dengan tipe principel,anggota organisasi akan cenderung mempertimbangkan hal-hal yang berkaitan dengan peraturan dan hukum. Dimensi kedua ethical climate work theory terdiri dari: individual, lokal, dan cosmopolitan. Pada lokus analisis individual dasar pengambilan keputusan dalam dilemma etis adalah moral individu. Lokus analisis lokal didasarkan pada ekspektasi yang datang dari organisasi seperti kode etik dalam organisasi. Lokus analisis cosmopolitan didasarkan dari luar individu dan organisasi, seperti kode etik yang dikeluarkan oleh asosiasi profesional yang menaungi organisasi tersebut. Organisasi dengan karakteristik egoism yang tinggi, anggota organisasi akan cenderung tidak melaksanakan tindakan whistleblowing.

Hasil uji hipotesis kedelapan pada Tabel 4 menunjukan bahwa intention whistleblowing tidak dapat memoderasi pengaruh komitmen organisasi terhadap whistleblowing behavior. Uji regresi moderat menunjukan bahwa nilai signifikasi sebesar 0,090 dapat dinyatakan lebih kecil dari 0,05 , sehingga dapat disimpulkan bahwa penelitian ini tidak mendukung hipotesis kedelapan (H8). Hasil penelitian ini memberikan bukti empiris bahwa intention tidak memperkuat komitmen organisasi dalam menaikkan perilaku (behavior) whistleblowing Aparatur Sipil Negara pemerintah. Penelitian ini sejalan dengan penelitian Salsabila (2018) dan Kamarunzaman et al. (2012), yang menyatakan bahwa komitmen organisasi tidak berpengaruh terhadap niat whistleblowing. Persepsi dukungan organisasi yang dirasakan merupakan salah satu faktor yang mendukung seorang individu untuk melaporkan tindakan tidak etis dalam organisasinya. Individu harus mengukur tingkat persepsi dukungan organisasi ketika ingin melakukan whistleblowing, mengingat akan muncul dampak negatif dan positif yang muncul seiring dengan whistleblowing yang dilakukan untuk itu dukungan organisasi sangat diperlukan oleh individu yang bersangkutan. Karyawan yang diperlakukan dengan baik akan cenderung lebih berkomitmen terhadap tempat kerja, dukungan organisasi juga akan mendorong karyawan untuk melaporkan whistleblowing (Kamarunzaman et al.,2013). Hal ini juga didukung penelitian yang dilakukan Abdilla (2017) berpendapat bahwa semakin tingginya ancaman (retalasi) maka niat untuk melakukan whistleblowing semakin berkurang. Dan juga didukung oleh penelitian Dananjaya \& Rizal (2018) bahwa niat seseorang untuk 
melaporkan kecurangan (whistleblowing) dapat berkurang atau hilang, Minat whistle-blowing juga dapat ditingkatkan dengan meningkatkan komitmen organisasi pegawai misalnya dengan pemberian kompensasi, reward dan punishment yang memadai; menciptakan lingkungan kerja yang kondusif dan terbuka sehingga pegawai dapat merasa terlibat dalam pelaksanaan tugas dan pencapaian tujuan organisasi, dan lain sebagainya, Hal ini menunjukkan bahwa karyawan yang memiliki komitmen terhadap organisasi belum dapat dipastikan untuk melakukan whistleblowing.

\section{SIMPULAN DAN SARAN}

\subsection{Simpulan}

Berdasarkan rumusan masalah, hipotesis dan hasil penelitian, maka dapat ditarik kesimpulan berikut:

1. Sikap berpengaruh terhadap Prilaku Whistleblowing pada Aparatur Sipil Negara di Inspektorat dan BPKP perwakilan Jambi. Pengaruh sikap terhadap Whistleblowing Behaviour dengan arah positif. Artinya meningkatnya sikap Aparatur Sipil Negara maka perilaku whistleblowing Aparatur Sipil Negara di Inspektorat dan BPKP perwakilan Jambi juga akan meningkat.

2. Niat (intention) tidak dapat memoderasi pengaruh sikap terhadap Perilaku whistleblowing (behavior) pada Aparatur Sipil Negara di Inspektorat dan BPKP perwakilan Jambi. Tidak Berngaruhnya dengan arah positif, yang artinya niat tidak dapat memperkuat sikap terhadap perilaku (Behaviour) whistleblowing pada Aparatur Sipil Negara di Inspektorat dan BPKP perwakilan Jambi.

3. Norma Subjektif tidak berpengaruh terhadap whistleblowing Behaviour pada Aparatur Sipil Negara di Inspektorat dan BPKP perwakilan Jambi. Tidak adanya Pengaruh Norma Subjektif terhadap Whistleblowing Behaviour dengan arah negatif. Artinya meningkatnya norma subjektif Aparatur Sipil Negara maka tidak meningkatkan perilaku whistleblowing ASN di Inspektorat dan BPKP perwakilan Jambi.

4. Niat tidak dapat memoderasi pengaruh norma subjektif terhadap perilaku whistleblowing pada Aparatur Sipil Negara di Inspektorat dan BPKP perwakilan Jambi. Tidak Berngaruhnya dengan arah positif, yang artinya niat tidak dapat memperkuat norma subjektif terhadap perilaku (Behaviour) whistleblowing pada Aparatur Sipil Negara di Inspektorat dan BPKP perwakilan Jambi.

5. Persepsi kontrol auditor berpengaruh terhadap whistleblowing Behaviour pada Aparatur Sipil Negara di Inspektorat dan BPKP perwakilan Jambi. Pengaruh persepsi kontrol terhadap Whistleblowing Behaviour dengan arah positif. Artinya meningkatnya sikap Aparatur Sipil Negara maka perilaku whistleblowing Aparatur Sipil
Negara di Inspektorat dan BPKP perwakilan Jambi juga akan meningkat.

6. Niat whistleblowing dapat memoderasi pengaruh persepsi kontrol terhadap whistleblowing behavior pada Aparatur Sipil Negara di Inspektorat dan BPKP perwakilan Jambi. Berpengaruhnya dengan arah positif, yang artinya niat dapat memperkuat meningkatkan persepsi kontrol terhadap perilaku (Behaviour) whistleblowing pada Aparatur Sipil Negara di Inspektorat dan BPKP perwakilan Jambi.

7. Komitmen organisasi tidak berpengaruh terhadap perilaku whistleblowing. tidak adanya pengaruh sikap terhadap Whistleblowing Behaviour dengan arah negative, artinya menurunnya komitmen organisasi tidak akan menaikkan perilaku whistleblowing Aparatur Sipil Negara di Inspektorat dan BPKP perwakilan Jambi

8. Niat whistleblowing tidak dapat memoderasi pengaruh komitmen organisasi terhadap whistleblowing behavior pada Aparatur Sipil Negara di Inspektorat dan BPKP perwakilan Jambi. Tidak Berpngaruhnya dengan arah negatif yang artinya niat tidak dapat memperkuat komitmen organisasi terhadap perilaku (Behaviour) whistleblowing pada Aparatur Sipil Negara di Inspektorat dan BPKP perwakilan Jambi.

\subsection{Saran}

Berdasarkan hasil penelitian dan pembahasan serta kesimpulan dalam penelitian ini, maka saran yang dikemukakan adalah sebagai berikut:

1. Untuk lebih meningkatkan sikap whistleblowing, maka Aparatur Sipil Negara pemerintah harus lebih meningkatkan belief streght dan outcome Evaluationnya.

2. Untuk meningkatkan norma subjektif Aparatur Sipil Negara pemerintah harus mengurangi kesempatan melalui ketaatan dan pemahaman pegawai terhadap peraturan perundang -undangan yang berlaku sanksi yang tegas dan adil sehingga menimbulkan efek jera. Pemerintah memberikan reward bagi auditor yang memiliki kompetensi dan integritas yang tinggi dalam kinerjanya dan dalam perilaku whistleblowingnya.

3. Untuk meningkatkan komitmen organisasinya auditor, maka diperlukan keterikatan emosional, keterlibatan yang tinggi dalam organisasi dan loyalitas auditor terhadap pemerintah.

4. Penerapan kebijakan whistleblowing tepat diterapkan ketika norma subjektif pada kondisi yang minim, sehingga para pimpinan di dalam suatu organisasi yang hendak menerapkan kebijakan whistleblowing harus mampu memotivasi anggota dalam organisasinya bahwa ada jaminan kerahasiaan dan perlindungan hukum terhadap pelapor. 
Pengaruh Sikap, Norma Subjektif, Persepsi Kontrol, dan Komitmen Organisasi Terhadap Whistleblowing Behavior dengan Intention Whistleblowing Sebagai Variabel Moderasi (Studi Pada Aparatur Sipil Negara di Inspektorat dan BPKP Perwakilan Jambi) (Achmad Fahmi Dj, Afrizal dan Ilham Wahyudi)

5. Pada lingkungan Pemerintah Provinsi tingkat keseriusan pelanggaran berbanding lurus dengan minat para pegawai melaksanakan tindakan whistleblowing, artinya semakin tinggi tingkat keseriusan pelanggaran maka semakin kuat niat pegawai melaksanakan tindakan whistleblowing, sehingga pimpinan dan tim kepatuhan internal harus lebih teliti dalam melakukan pemantauan pengendalian intern, pengelolaan kinerja, pengelolaan risiko, dan pemantauan kepatuhan terhadap kode etik dan disiplin agar setiap pelanggaran/ kecurangan yang sifatnya kurang dianggap serius tetap dapat terdeteksi.

6. Peneliti selanjutnya disarankan menambahkan data berupa hasil wawancara dari beberapa ASN yang menjadi responden penelitian.

\section{DAFTAR REFERENSI}

Ajzen, I. (1991). The Theory of Planned Behavior. Organizational Behaviour and Human Decision Processes, Vol.50, No.2 : 179 - 211

Ajzen,I.(2005). Attitudes,personality and behavior. Berkshire : Open University Press

Alleyne, P, M.Hudaib, dan R. Pike. (2013). Towards a Conceptual Model of Whistleblowing Intention Among External Auditors. The British Accounting Review, 45: 10-23

Bobek,Donna d,dan Hatfield, Richard C .(2003). An examination of the theory of planned behavior and the role of moral obligation in tax compliance.Behavioral Research in Accounting,Vol 15: pp.13-38

Bowen, R. M., Call, A. C., \& Rajgopal, S. (2010). Whistle-blowing: Target firm characteristics and economic consequences. Accounting Review. 85(4), 1239-1271. https://doi.org/10.2308/accr.2010.85.4.1239

Brief,A.P dan S.J Motowidlo.(1986). Prosocial Organizational Behaviours.Academy of Management Review 11 (4) page 710-725

Buchan, H. F. 2005. Ethical decision making in the public accounting profession: An extension of Ajzen theory of planned behavior. Journal of Business Ethics.61(2): 165-181

Carpenter,Tina D,and Reimers,Jane L. 2005. Unethical and fraudulent financial reporting,applying the theory of planned behavior;Journal of Bussines Ethics.Vol.60.No.2: pp.115-129

Cooper, Donald R and Schindler, Pamela S, 2017. Metode Penelitian Bisnis Edisi 12 , Buku 1 : Penerbit The Mc Graw-Hil Companies, Inc

Curtis, MB. and EZ Taylor. (2009). Whistleblowing in Public Accounting; Influence of Identity Disclosure, Situational Context and Personal
Characteristics. Accounting and the Public Interest $\square$ in press

Dozier, J B. dan MP. Miceli. (1985). Potential Predictors of Whistleblowing; A Prosocial Behavior Perspective. Academy of Management Review 10 (4), 823-836

Fishbein, M., \& Ajzen, I. (1975). Belief, attitude, intention and behavior: An introduction to theory and research. Reading, MA: Addison-Wesley

Indriantoro,Nur dan Supomo,Bambang.(2014). Metodologi Penelitian Bisnis untuk Akuntansi dan Manajemen.Edisi pertama,BPFE,Yogyakarta

Jogiyanto HM. (2007). Sistem Informasi Keperilakuan.Yogyakarta: CV.Andi Offset

Lubis, A. I. (2010), Akuntansi Keperilakuan Jakarta: Salemba Empat

Komite Nasional Kebijakan Governance.(2008). Pedoman system pelaporan pelanggaran-SPP (Whistleblowing System-WBS)

Mahmudah, Hadi. dan Riyanto, BambangLS. (2016). Keefektifan Audit Internal Pemerintah Daerah. Jurnal Akuntansi /Volume XX, No. 01, Januari 2016: 33-51

Miceli, M. P. dan J. P. Near (1988). Individual and Situational Correlates of Whistleblowing. Personnel Psychology 41(2), 267-281

Montesarchio, cathilee E. (2009). Factor influencing the unethical behavior,intention of college business students theory of planned behavior.Disertation lynn University. www.Proquest.com

Park \& Blenkinsopp .(2009). Whistleblowing as Planned Behavior,A Survey of South Korean Police Officers. Journal of Business Ethics 85:545-556

Penner,L.A ； Dovidio,J.F.;Piliavin,J.A.; dan Schroeder,D.A. (2005). Prosocial Behavior ; Multilevel Perspectives. Annu.Rev.Psychol, 56:365-392

Ponnu,C.H.K.Naidu, and W. Zamri. (2008).Determinants of Whistle Blowing. International Review of Business Research Papers, Vol.4, No.1 page : 276 -298

Respati, N, W.(2011). Determinan Perilaku Manajer dalam Melakukan Kecurangan Penyajian Laporan Keuangan. Simposium Nasional Akuntansi XIV. Aceh.

Rosthschild,J. \& Miethe,T.D.(1999). Whistle-blower disclosures and management retaliation.The Battle to control information about organization corruption.work and occupation.26 (1):107-128

Su,Chin-chun dan Ni,Feng yu.(2013). Budgetary participation and slack on the theory of planned 
behavior.International Journal of Organizational Innovation.Vol.5,No.4:pp 91-99

Tempo. (2019) <https://nasional.tempo.co/read/896611/ ott-kpk-di-pamekasan-bupati-dan-

kepalakejaksaan-jadi-

tersangka/full\&view $=$ ok $>[10 / 1 / 19]$

Tempo.(2019)

<https://nasional.tempo.co/read/1067923/eks-

auditor-bpkp-akui-terima-duit-dari-panitia-lelange-ktp/full\&view $=$ ok $>$ [10/1/19]

Trongmateerut, P. dan J. T. Sweeney. (2013). The Influence of Subjective Norms on WhistleBlowing: A Cross-Cultural Investigation. Journal of Business Ethics, 112 (3), 437-451.

Uddin,Nancy,dan Gillet,Peter R.(2002). The effects of moral reasoning and self-monitoring on $\mathrm{CFO}$ intentions to report fraudulently on financial statements.Journal of business Ethics.Vol.40,No.1 :pp 15-32

Vallerand, R. J. et al. (1992). Ajzen and Fishbein's Theory of Reasoned Action as Applied to Moral Behavior: A Confirmatory Analysis. Journal of Personality and Social Psychology, 62 (1): 98109 